Article

\title{
Interrogating Climate Adaptation Financing in Zimbabwe: Proposed Direction
}

\author{
Innocent Chirisa ${ }^{1,2, *}$, Trynos Gumbo ${ }^{3} \mathbb{D}$, Veronica N. Gundu-Jakarasi ${ }^{4}$, Washington Zhakata ${ }^{5}$, \\ Thomas Karakadzai ${ }^{6}$, Romeo Dipura ${ }^{7}$ (D) and Thembani Moyo ${ }^{3}$ (D)
}

1 Department of Demography Settlement and Development, Faculty of Social and Behavioural Sciences, University of Zimbabwe, Harare 263, Zimbabwe

2 Department of Urban and Regional Planning, Faculty of Natural and Agricultural Sciences, University of the Free State, Johannesburg 277, South Africa

3 Sustainable and Smart Cities and Regions Research Group, Department of Urban and Regional Planning, University of Johannesburg, Johannesburg 277, South Africa; tgumbo@uj.ac.za (T.G.); tmoyo@uj.ac.za (T.M.)

4 Infrastructure Development Bank of Zimbabwe (IDBZ), Harare 263, Zimbabwe; verogundu@gmail.com

5 Ministry of Environment, Climate, Tourism and Hospitality, Government of Zimbabwe, Harare 263, Zimbabwe; washingtonzhakata@gmail.com

6 Dialogue on Shelter, Harare 263, Zimbabwe; thomkarakadzai27@gmail.com

7 Africa Centres for Cities, University of Cape Town, Cape Town 7701, South Africa; rsdipura@gmail.com

* Correspondence: ichirisa@sociol.uz.ac.zw

check for updates

Citation: Chirisa, I.; Gumbo, T.; Gundu-Jakarasi, V.N.; Zhakata, W.; Karakadzai, T.; Dipura, R.; Moyo, T. Interrogating Climate Adaptation Financing in Zimbabwe: Proposed Direction. Sustainability 2021, 13, 6517 https://doi.org/10.3390/su13126517

Academic Editor: Olaf Weber

Received: 18 March 2021

Accepted: 11 May 2021

Published: 8 June 2021

Publisher's Note: MDPI stays neutral with regard to jurisdictional claims in published maps and institutional affiliations.

Copyright: (C) 2021 by the authors Licensee MDPI, Basel, Switzerland. This article is an open access article distributed under the terms and conditions of the Creative Commons Attribution (CC BY) license (https:// creativecommons.org/licenses/by/ $4.0 /)$.
Abstract: Reducing vulnerability to climate change and enhancing the long-term coping capacities of rural or urban settlements to negative climate change impacts have become urgent issues in developing countries. Developing countries do not have the means to cope with climate hazards and their economies are highly dependent on climate-sensitive sectors such as agriculture, water, and coastal zones. Like most countries in Southern Africa, Zimbabwe suffers from climate-induced disasters. Therefore, this study maps critical aspects required for setting up a strong financial foundation for sustainable climate adaptation in Zimbabwe. It discusses the frameworks required for sustainable climate adaptation finance and suggests the direction for success in leveraging global climate financing towards building a low-carbon and climate-resilient Zimbabwe. The study involved a document review and analysis and stakeholder consultation methodological approach. The findings revealed that Zimbabwe has been significantly dependent on global finance mechanisms to mitigate the effects of climate change as its domestic finance mechanisms have not been fully explored. Results revealed the importance of partnership models between the state, individuals, civil society organisations, and agencies. Local financing institutions such as the Infrastructure Development Bank of Zimbabwe (IDBZ) have been set up. This operates a Climate Finance Facility (GFF), providing a domestic financial resource base. A climate change bill is also under formulation through government efforts. However, numerous barriers limit the adoption of adaptation practices, services, and technologies at the scale required. The absence of finance increases the vulnerability of local settlements (rural or urban) to extreme weather events leading to loss of life and property and compromised adaptive capacity. Therefore, the study recommends an adaptation financing framework aligned to different sectoral policies that can leverage diverse opportunities such as blended climate financing. The framework must foster synergies for improved impact and implementation of climate change adaptation initiatives for the country.

Keywords: adaptive capacity; climate change adaptation; policy; adaptation finance; resilience; sustainability; vulnerability; Global South; wealthier countries; developing countries 


\section{Introduction}

Climate change, induced by many different kinds of human activities, has continued to dominate the global environmental governance agenda for the past two decades [1-4]. However, despite planning for climate change adaptation strategies being regarded as a vital element of climate policy in many countries, the practical execution of adaptation actions is in its initial stages [5-7]. As an example, no study has interrogated climate adaptation financing in Zimbabwe to propose a stylised framework. Nevertheless, studies on climate change adaptation have advanced significantly in the past decade, making significant contributions. For instance, scholars have established approaches for evaluating vulnerability in different locations and documenting comprehensive strategies. Furthermore, barriers and opportunities have been identified that led to adaptation and improved adaptive capacity [8-10].

The vulnerability of different sectors such as agriculture, forestry, water and sanitation, and health, along with biodiversity, ecosystems, and infrastructure to climatic changes is constantly demanding increased, innovative, and transformational adaptation interventions. This is pertinent in building resilient systems and highly adaptable communities. According to the IPCC (2014), Africa is one of the most vulnerable continents to the impacts of climate change. The reverberations of climate change have not spared Africa, with both human and natural systems being immensely affected. Africa's vulnerability has been attributed to its reliance on agriculture, which is highly sensitive to weather and climate variables (e.g., temperature, precipitation, and light) and extreme weather events. Climate change is posing greater risks of pests and diseases to the continent's agricultural systems, thereby affecting crop, livestock, and fisheries productivity. Globally, agricultural productivity has declined by $1-5 \%$ per decade due to climate change [11]. The unpredictable, sporadic, and intermittent weather patterns have placed an additional burden on agriculture, posing an extra threat to the region's gross domestic product, employment, food and nutrition security, and rural livelihoods. According to the Zimbabwe Vulnerability Assessment Committee, the global acute nutrition rate of children between 6-59 months reached $5.7 \%$, which was the highest recorded in 15 years [12].

Africa's water resources have not been spared by climate change. The recurrent droughts alternating with floods indicated by recent trends have resulted in increased sea-level rise, receding water table, reduced water quality, drying of water bodies, and contortions of precipitation and water vapour patterns [13]. Water scarcity has put pressure on Africa's development pathway and Egypt, Ethiopia, and Sudan are trapped in water wars following the development of the Grand Ethiopian Renaissance Dam [14].

Additionally, Africa is endowed with natural resources, including wildlife, forests, and rich biological diversity. Whilst these natural resources are exposed to human pressure due to overreliance, and habitat fragmentation, biodiversity loss and external pressure have also been attributed to climate change. Climatic changes are increasingly affecting species distribution and abundance, leading to biodiversity loss. Changes in the function of the ecosystems and constituents of biodiversity can have knock-on effects. There is a need for reliable and quality predictions on the likely effects of climate change on biodiversity to inform and finance effective biodiversity conservation and management strategies [13,14]. Implementing planning and prioritizing win-win adaptation strategies across different sectors is important in informing the funding sources and financing structures that can be used for identified adaptation interventions.

To evaluate the capacities a system might (or might not) have, there is a need to plan towards adaptation or adaptation barriers. One of these concentrates on evaluation techniques of barriers to adaptation, crucial to recognizing probable challenges to the adaptation procedure [15]. Some identified barriers leading to climate change adaptation include the knowledge gap regarding the uncertainty of disaster effects, poor leadership, and lack of finances to support initiatives. Further institutional constraints could be rigidity leading to the failure of climate adaptive initiatives [16]. 
Sound climate change adaptation policies ensure sustainable development practices that can engage stakeholders and overcome political and social barriers for effective action [10]. As an example, in the water sector, various frameworks have been developed to differentiate between types of adaptation. Such differences have been categorized as planned adaptations that respond directly to climate change and unplanned adaptations that are not precisely modelled with climate change in mind [17]. In the UK, both planned and unplanned adaptation is used for flood risk management to assess water demand and supply. Both the private and public sector are actively involved in strategies towards building adaptive capacity. Research on adaptive capacity's response to stresses reveals numerous determinants of adaptive capacity occurring for discrete time and locations [18]. Such research has been used to outline how authorities and stakeholders are involved in the planning and governance processes for adaptation actions [19-21].

Zimbabwe, like most of Southern Africa, is experiencing severe climate-induced disasters. This strongly impacts the country as it is reliant on climate-sensitive sectors such as farming. Efforts have been made by the Zimbabwean government to lessen vulnerability to climate change and to improve the long-term coping capacities of communities in dealing with climatic impacts. However, Zimbabwe lacks the means to handle extreme climate hazards, and the mechanisms to adopt to enhance climate adaptation financing are unclear. Consequently, this study examines the critical aspects that are in place and those needed for a strong financial foundation for sustainable climate adaptation. The article explores the current state of finance for climate adaptation and proposes practical, short-term solutions to fill in knowledge gaps and to increase investment, including the use of blended financing. It is strongly believed that developing, adopting, and implementing a local climate adaptation financing framework will leverage global climate financing and facilitate the realisation of a low-carbon (adaptation co-benefits) and climate-resilient Zimbabwe.

The study makes a new contribution to knowledge by providing data from a concrete example in the Global South. Research findings from Zimbabwe help to clarify some of the challenges and achievements that different actors face as they seek to provide effective responses to climate change. The paper complements existing literature by highlighting key factors that have to be taken into account when generating policies and actions to promote climate adaptation finance and practice. It provides fresh perspectives to the existing international literature through thick descriptions of the situation in one country that is seeking to embrace good practices from elsewhere around the globe.

\section{Literature Review}

This section discusses various concepts informing the study. These include barriers to adaptation, climate adaptation finance, and the essential criteria for adaptation financing mechanisms.

\subsection{Clarification of Key Concepts}

Adaptation relates to the regulating policies employed to minimise potential climate change impacts and to promote enhanced adaptive capacity of people and systems [22]. Such adaptation strategies represent directional change socio-ecological systems. They can be purposely planned or developed separately with the goal of a normative situation that can address current or future climate risks while remaining adaptive to future changes [16]. Adaptation is described by the United Nations Framework Convention on Climate Change [23] as "the process through which societies increase their ability to cope with an uncertain future that involves taking appropriate action and making the adjustments and changes to reduce the negative impacts of climate change". Adaptation can happen at several diverse levels. For instance, individuals, community members, and the private and public sectors can all contribute $[6,24]$. 
Research on climate change adaptation makes the point that each local settlement (rural or urban) has numerous levels of vulnerability and resilience, making each condition unique $[10,25]$. Impacts of climatic changes on socio-economic and natural systems are also likely to be felt and responded to regional/local levels because of heterogeneous circumstances of individual local settlements (rural or urban) which necessitate more localised studies [26]. Given that resources are generally unevenly distributed, the impacts of climate change vary across different locations. Likewise, similar climate change events will produce varying socio-economic impacts at different times and locations. Additionally, the local communities' agility and resources will not be the same, thus affecting how the community is impacted by climate change [27]. Consequently, the relative successes in dealing with climate change impacts differ depending on location, industrial sectors, and communal attributes [28]. Furthermore, adaptation becomes incremental when facilities and strategies are inadequate to mitigate the impacts of climate change [27]. This calls for investments to build and develop communal facilities, as shown in Table 1 [29].

Table 1. Barriers to adaptation. Source [29].

\begin{tabular}{|c|c|c|}
\hline Barrier Type & Barrier Name & Definition \\
\hline \multirow{4}{*}{ Context Barriers } & Poor policy environment & $\begin{array}{l}\text { Absence of supportive conditions to sector-specific } \\
\text { investment in the policy environment (e.g., no } \\
\text { requirements for businesses to implement disaster risk } \\
\text { management strategies) }\end{array}$ \\
\hline & Poor institutional environment & $\begin{array}{l}\text { Legal and regulatory organisations and infrastructure } \\
\text { supporting investment are absent } \\
\text { (e.g., contract enforcement, property rights, permitting, } \\
\text { rule of law, etc.) }\end{array}$ \\
\hline & Poor market environment & $\begin{array}{l}\text { Unsupportive market environment to sector-specific and } \\
\text { general investment (e.g., a weak economy, } \\
\text { inexperienced financial institutions, weak historic track } \\
\text { record of sector-specific investment, etc.) }\end{array}$ \\
\hline & Poor value chains and human capital & $\begin{array}{l}\text { Environment lacks the organisations and people with } \\
\text { the required competencies for the investment to occur } \\
\text { and be effective (e.g., absence of sector-specific value } \\
\text { chain or local sectoral knowledge) }\end{array}$ \\
\hline \multirow{3}{*}{ Business model barriers } & Uncertain or unknown value-added & $\begin{array}{l}\text { Absence of knowledge concerning value or benefit of } \\
\text { the technology to users or is uncertain; lack of } \\
\text { consideration of climate risk in decision-making }\end{array}$ \\
\hline & High cost & Too high upfront and operational costs of technology \\
\hline & Lack of technical capacity & $\begin{array}{l}\text { Potential users of the technology do not have the } \\
\text { technical capacity that is required in implementation } \\
\text { or technology use }\end{array}$ \\
\hline Internal capacity barriers & Lack of internal capacity & $\begin{array}{c}\text { Internal management and operational capabilities of } \\
\text { the adaptation product or service provider } \\
\text { are inadequate to scale }\end{array}$ \\
\hline
\end{tabular}

From Table 1, a distinction between the barriers to climate adaptation is made. It is noted that different contexts possess different factors that inhibit how climate adaptation is done. Similarly, there are modifiable filters for representing the current context that only offer the minimal required functions for adaptive responses, on the one hand [30]. For instance, in contexts where the environmental policy is poor, climate adaptation tends to be poorly managed. Lack of technical capacity is another barrier when dealing with climate adaptation at the national, household, and individual level.

On the other hand, developmental adaptation is applied with limited capacity and investment in developing countries when there is a persistent need to resolve climate risks that are current and emerging [31,32]. While research on unpacking climate change and 
its implications has grown, there is still a need for more research to unpack the practical guidance of adaptation. This calls for essential criteria for adaptation financing mechanisms, as shown in Table 2 [33].

Table 2. Essential criteria for adaptation financing mechanisms. Source [33].

\begin{tabular}{|c|c|}
\hline Criterion & Description \\
\hline $\begin{array}{l}\text { Developed in an environment that is } \\
\text { sufficiently predictable }\end{array}$ & $\begin{array}{l}\text { To enable the private sector to invest with confidence, policy direction, tools, and } \\
\text { instruments (i.e., the architecture supporting adaptation projects) need to be } \\
\text { sufficiently predictable, both in scope and time. }\end{array}$ \\
\hline Generate ROI & $\begin{array}{l}\text { The private sector will only invest when there is an attractive risk-adjusted return on } \\
\text { investment. One of the most crucial elements for creating a viable investment vehicle } \\
\text { for the right type of private sector investment is the identification of a way to reduce } \\
\text { risk sufficiently to enable a predictable, low risk, single-digit return over the long term. }\end{array}$ \\
\hline Measurable & $\begin{array}{l}\text { A critical constituent of any financial vehicle will be to define and develop reliable } \\
\text { metrics that speak directly to private sector concerns at the investment level. }\end{array}$ \\
\hline Politically attainable & $\begin{array}{l}\text { In theory, the best private finance mechanism would not require any } \\
\text { governmental action. In reality, addressing the climate adaptation challenge will } \\
\text { require a coordinated, aligned, and productive relationship } \\
\text { between the private sector and government. }\end{array}$ \\
\hline Environmentally sound & $\begin{array}{l}\text { Privately financed climate adaptation funding will be counter-productive if it } \\
\text { exacerbates climate change unacceptably. }\end{array}$ \\
\hline
\end{tabular}

Table 2 provides a toolkit that outlines a range of tools that can assist countries to navigate the evolving architecture of climate finance and access opportunities for adaptation finance. The essential criteria are not prescriptive, intrusive, or exhaustive, but provide practical and technical solutions. The development of adaption should be part of the national mandate that informs capacities at the national and local levels, thus creating opportunities for investment [5]. This study provides key elements on how to develop a Climate Adaptation Financing Framework, with specific lessons from what has worked in other developing countries and building on lessons of their failures.

Planners and decision-makers further need to combine efforts to mitigate climate change causes and adapt to changing climatic conditions (adaptation). Therefore, actions promoting both goals provide win-win solutions [34]. Understanding climate risk and internalising it into financial decision-making by evaluating the vulnerability, exposure, and response to the climate are essential both for reducing susceptibility and market risk of investments to adverse climate impacts. It helps to identify opportunities to invest in climate resilience, including aligning the financial system toward such investments [35,36]. The financial system has numerous factors that influence climate risk and are informed by policy and regulatory systems. Effective adaptation and climate-resilient development in different countries is predicated on proper access to financial, technological, and human resources [37]. Given the growth in climate impacts and barriers, the impacts on developing countries, particularly those that are highly vulnerable, are vast. The Government of Zimbabwe's fiscus is financially constrained to address the additional costs associated with climate change. In other words, climate finance needs and current revenue-generating mechanisms are not equal [38]. There is a need for blended finance approaches that will attract philanthropic development capital to crowd in private sector financing to support adaptation, mitigation, and SDG-related investments that include financing infrastructure development and maintenance and institutions for monitoring and evaluation [39]. Blended financing can reduce Zimbabwe's over-reliance on global funding but also explore private sector domestic and philanthropic funding. Hence, Zimbabwe can explore the opportunities from novel initiatives such as blended financing and issuing green bonds. 


\subsection{Climate Adaptation Finance}

Both developed and developing countries experience climate adaptation finance deficits. Global climate change is occurring and will continue to change in the coming century at rates projected to be unprecedented in current human history. The susceptibility of people and local settlements is determined by the entitlement of individuals and communities to call on these resources [40]. Governments thus fulfil vital roles in creating an enabling environment that promotes the adaptive capacity of communities and empowers them to be able to respond to impacts of climate change [41].

Policy debates are ever-increasing with regards to climate change adaptation. Climate change conventions recognise different forms of adaptation and the activities suitable for funding including the areas of adaptation and capacity-building [42]. For example, the UN Framework Convention on Climate Change conference (2004) "agreed to develop a five-year structured programme of work on the scientific, technical and socio-economic aspects of impacts, vulnerability and adaptation to climate change". The result has been that many EEA member nations in the Global North have adjusted their overall national climate policy framework to include climate change adaptation as an equally important mitigating component [43]. For instance, Germany, the United States of America, and Northern Ireland have developed national adaptation strategies to address the impacts of climate change. Consequently, a wide range of adaptation responses have been introduced at different governmental levels and in diverse sectors. The EU and several of its member countries have offered provision for extensive financial and technical assistance to aid less developed nations in their adaptation efforts. One initiative was the Green Climate Fund, which was projected to play a noteworthy role in financing adaptation as it reached an equal split between adaptation and mitigation [36]. It also provided support for national adaptation plans formulation through the Green Climate Fund Readiness and Preparatory Support Programmes.

In Global South countries such as Togo, Sudan, South Africa, Brazil, and Jamaica, national adaptation plans (NAPs) are evolving to become tools that utilize numerous adaptation efforts into sustainable and comprehensible strategies. The NAPs are informed by an eight-step framework that is localized and not a holistic adaptation plan. The objective is to address local problems of climate change by developing local project initiatives that prioritise efficiency during the implementation and formulation stages [44]. Unlike in developed countries, developing countries lack the institutional and financial capacity and tools to invest in climate change adaptation efforts.

The other example of a regional programme that was launched precisely to address adaptation to climate change is the Africa Adaptation Initiative. This was established at the 25th African Union Summit in June 2015 in response to a mandate by the African Heads of State to enhance adaptation efforts in Africa in the context of the UNFCCC process and the Green Climate Fund [45]. The initiative was developed as a result of the urgency in Africa for adaptation and the need to enhance support to scale up and accelerate adaptation actions.

These international institutions and policies are dominated by global managerialism [46]. This has led to a distortionary focus in the mandate to "planned adaptation" at both a local and global level. However, there has been a growth in divergent views on the "how", "what", and "when" of adaptation and its contribution to the sustainable development agenda. Climate change brings about new challenges for natural resource planning and management. Adaptation then becomes an inevitable process that constitutes negotiated adjustments between stakeholders and renegotiation of risk-sharing and bearing.

In light of the vulnerability of areas in the developing world that have limited adaptive capacity, international funds were proposed under the Convention and its Kyoto Protocol. Examples include the Special Climate Change (SCC) Fund which assists technology transfer and adaptation, the Kyoto Protocol Adaptation Fund which funds local adaptation programmes, and Least Developed Countries Fund which funds efforts to develop national adaptation programmes of action [38,47-50]. The Adaptation Fund has increasingly made strides to empower countries to be accredited to the Fund. This assists them to cut the high transaction costs associated with intermediaries such as the United Nations and 
other big agencies such as the World Bank that charge over $10 \%$ for project management. Nevertheless, efforts to develop climate change adaptation have faced many barriers as they have to consider multiple political and socio-economic challenges. Common challenges to be addressed in developing countries include gender inequality, corruption, and poverty [51]. Scholars have outlined that the current adaptation efforts can be viewed as incremental adaptation [52,53], as these address problems at a local scale to become sustainable initiatives that address climate change [53,54].

Taking the above review into account, Africa's vulnerability to climate change creates a call at both national and local levels to finance adaptation activities, to address historical trends whereby very little financing was undertaken to assist adaptation efforts in this region [55]. Notwithstanding the current increase in approved finance globally, Africa is still receiving a relatively small proportion. An example is in 2011, when the climate finance approved funding for 31 projects globally, but only five projects were funded in Africa. Table 3 lists the contributions of dedicated climate funds monitored by Climate Fund Update to adaptation in Sub-Saharan Africa [7].

Since 2001, the Least Developed Countries Fund (LDCF) has funded the highest number of adaptation projects, with approximately USD 60 million distributed across 49 projects. For African communities, efforts are still needed to ensure that socio-economic challenges are addressed to ensure the success of climate adaptation projects. Furthermore, there is a need to simplify approaches to estimating adaptation costs for various locations and climate scenarios to reduce uncertainties. However, through community-based adaptation, means are being developed to build capacity and develop resilience to enable recovery [56].

Table 3. Contributions of dedicated climate funds to adaptation in SSA. Source [7].

\begin{tabular}{cccc}
\hline Fund Name & $\begin{array}{c}\text { Amount Approved } \\
\text { (USD m) }\end{array}$ & $\begin{array}{c}\text { Amount Disbursed } \\
\text { (USD m) }\end{array}$ & $\begin{array}{c}\text { Number of } \\
\text { Projects Disbursed }\end{array}$ \\
\hline $\begin{array}{c}\text { Global Climate } \\
\text { Change Alliance }\end{array}$ & 52 & 22 & 5 \\
\hline $\begin{array}{c}\text { International Climate } \\
\text { Initiative }\end{array}$ & 12 & 4 & 2 \\
\hline Adaptation Fund & 15 & 60 & 49 \\
\hline $\begin{array}{c}\text { Least Developed } \\
\text { Countries Fund }\end{array}$ & 90 & 12 & 3 \\
\hline $\begin{array}{c}\text { Special Climate } \\
\text { Change Fund }\end{array}$ & 20 & 13 & 0 \\
\hline $\begin{array}{c}\text { Millennium Development } \\
\text { Goal Fund }\end{array}$ & 16 & 0 & 70 \\
\hline $\begin{array}{c}\text { Pilot Program for } \\
\text { Climate Resilience }\end{array}$ & 114 & 123 & \\
\hline Total for SSA & 319 & 4 & 5 \\
\hline
\end{tabular}

\subsection{Rationale for Climate Adaptation Finance}

Climate finance enables stakeholders and decision-makers to be involved in the planning process and development of appropriate approaches for the growth and support of the transit towards green, low-emission, and climate-resilient development.

It should be noted that climate finance provides a community-driven system that can support climate change and strategic programming. It creates the ability to oversee the approval process and quantify project implementation and performance; it informs efforts to build partnerships that support policy and financial strategies [32,33]. However, climate finance must be carefully designed to align with national objectives and capacities on climate change. National climate funds are not "one-size-fits-all", but must be designed to create enabling environments for concessional loan and grant climate finance at the 
local and national level $[11,38]$. For example, in Africa, Rwanda is regularly portrayed as a pioneer country in its efforts to address climate finance readiness needs and challenges: "In 2015, the Rwandan government commissioned a climate change vulnerability index to estimate vulnerability at national and household levels and to assess how investments in climate resilience have paid off" [57]. This highlights that exposure and sensitivity are higher than adaptive capacities in various locations. It is against this backdrop that Rwanda has improved its responses by actively seeking synergies towards adaptation through aligning policies and procedures at all levels. Through these actions, it has created a springboard to amass an excess of USD 130 million as a local climate finance base [58,59].

Furthermore, the effectiveness of climate finance can be assessed through promoting clear developmental aims that are understood by the local community and developing support mechanisms. It should balance public and private capital, use a results-based approach that considers cost-effectiveness, and support actions aligned with national priorities (that are also administered transparently with predictable financing) [60]. Above all, the prerequisite of climate change finance hinges on aligning the policy environment for climate change investment [61]. This mainstreaming of climate change adaptation within existing national planning and evaluation systems helps to streamline workflow and generate buy-in from implementers [62]. To prioritise investments, stakeholders and community members have to appreciate the impacts of climate risks on a local and national scale [63]. However, unlike Rwanda, where the climate change landscape is properly coordinated, evidence in Zimbabwe indicates that efforts towards building a climate finance platform are still embryonic [64]. Nevertheless, a climate change bill is being crafted that seeks to establish a finance vehicle towards issues of adaptation, mitigation, and capacity building.

Ownership of adaptation initiatives poses a significant challenge of coordination at multiple levels and key stakeholders at the national level [64]. Operational and political focal points aid as the interface between national and the Global Environment Facility, and must support proposals so they can be approved for funding [30,55].

\section{Methods and Materials}

The study used a qualitative research approach, including a document review and analysis that provided a systematic procedure for identifying, analysing, and deriving useful information from existing documents. A review was conducted of the international literature on climate change finance and the context where this takes place in Africa and Zimbabwe. The review was meant to establish current trends in other developing or developed countries. The selection of the review documents was informed by the success stories that have advanced their work in climate finance. In particular, reference was made to the Rwanda Green Climate Fund, the Kenya Climate Finance Department in the Ministry of Finance, and the Development Bank of Southern Africa Climate Finance Facility. Zimbabwe climate change policies and strategy documents were also reviewed to understand the funding required to support climate action in Zimbabwe and how it could be mobilised for high-priority sectors. Additionally, themes were identified that clarified the envisaged future of climate finance in Zimbabwe. This was achieved through focus group discussions (FGDs) conducted with different stakeholders using nonprobability targeted sampling. This included government ministries and parastatals (e.g., Ministry of Finance and Economic Development, Ministry of Agriculture, Ministry of Environment, Climate Change Management Department, Environmental Management Agency, etc). Local authorities, non-governmental organisations, academia, development partners, and the private sector were also included in the sample. FGDs were also conducted with farmers from purposively sampled districts (Domboshava, Lupane, Chirumanzu, Seke, Chiredzi, Mberengwa, Bulilimamangwe, Gwanda, Zvishavane, and Gutu) across different agro-ecological zones about the different adaptation strategies that they were applying. Focus group discussions for the stakeholders included 10 questions that determined what they understood by climate finance and what Zimbabwe could do to mobilise climate finance in the future. One national FGD and three sub-national FDGs were held, whilst 
10 FDGs were held with a total of 133 farmers drawn from the 10 provinces sampled. Each FDG was limited to $2 \mathrm{~h}$, and ethical considerations including informed consent and anonymity were observed. The farmers' FDG guide contained 15 questions including understanding the impacts of climate change and the adaptation strategies that they were employing to address it and enhance their long-term capacity to cope with it. Key informant interviews were conducted with the Ministries of Environment and Finance as the primary stakeholders in the climate finance field. For this purpose, an interview guide with 10 questions was created. It was grouped into three themes that related to climate change policy, climate change adaptation, and climate finance, and each interview was kept to no longer than $40 \mathrm{~min}$. Targeted sampling was used to access focus group stakeholders and key informants, although snowball sampling was used, following recommendations made during the FDGs and the interviews. The interviews sought to get in-depth information about Zimbabwe's climate adaptation financing landscape, opportunities, and constraints. The consultations were conducted over a period of 6 months (see Table 4).

NVIVO was used to analyse the data collected from the FGDs and the interviews, and key themes were identified including sectoral adaptation in the water sector, agriculture sector, natural resources (forestry and biodiversity sector), and human settlements, among others.

The study included a limited sampling of key informants at the national level due to shortages of resources to cover the whole country at sub-national levels. The study focus was climate finance from an adaptation perspective, therefore limiting the climate finance opportunities and lessons from a mitigation perspective. Time was also not adequate to conduct investigations in all the districts of interest (see Figure 1).

- Literature Review and Analysis

-4 Focus Group Discussions with Climate Finance Stakeholders (1 national and 3 subnational)

-10 Focus Group Discussions with Farmers from 10 districts

-7 Key Informant Interviews were done with Key respondents in climate Finance including the Stage 3 Ministry of Finance and Ministry of Environment

-Data Entry, Cleaning and Analysis using NVIVO and themes

Figure 1. Graphical representation of the methodology. Source: authors. 
Table 4. Profile of interviewees.

\begin{tabular}{|c|c|c|}
\hline Interviewee Group & List of Respondents & Form of a Consultative Method \\
\hline $\begin{array}{c}\text { Climate Finance Stakeholders } \\
\text { Government Ministries and } \\
\text { Parastatals, } \\
\text { Development Partners } \\
\text { Academia } \\
\text { Non-Governmental Organisations }\end{array}$ & $\begin{array}{ll}\text { - } & \text { Ministry of Finance and Economic Development } \\
\text { - } & \text { Ministry of Agriculture } \\
\text { - } & \text { Environmental Management Agency } \\
\text { - } & \text { Forestry Commission } \\
\text { - } & \text { Parks and Wildlife Management Authority } \\
\text { - } & \text { Climate Change Management Department } \\
\text { - } & \text { Meteorological Services Department } \\
\text { - } & \text { Hariculture Extension Department } \\
\text { - } & \text { Bulawayo City } \\
\text { - } & \text { Mutare City } \\
\text { - } & \text { Masvingo City } \\
\text { - } & \text { Gasvingo Rural } \\
\text { - } & \text { UNDP } \\
\text { - } & \text { FAO Rural } \\
\text { - } & \text { Schweppes } \\
\text { - } & \text { Business Council for Sustainable Development } \\
\text { - } & \text { Zimbabwe } \\
\text { - } & \text { Zimbabing Volunteers for Environment (YVE) } \\
\text { - } & \text { Zimbabwe Environment Regional Organisation } \\
\text { - } & \text { University of Zimbabwe } \\
\text { - } & \text { Bindura University of Science Education }\end{array}$ & Focus Group Discussions \\
\hline Farmers & $\begin{array}{l}\text { No more than } 15 \text { farmers were drawn from } 10 \text { districts: } \\
\text { - } \quad \text { Domboshava } \\
\text { - } \quad \text { Lupane } \\
\text { - } \quad \text { Chirumanzu, } \\
\text { - } \quad \text { Seke } \\
\text { - } \quad \text { Chiredzi } \\
\text { - } \quad \text { Mberengwa } \\
\text { - } \quad \text { Bulilimamangwe } \\
\text { - } \quad \text { Gwanda } \\
\text { - } \quad \text { Zvishavane } \\
\text { - } \quad \text { Gutu }\end{array}$ & Focus Group Discussions \\
\hline $\begin{array}{c}\text { Key Informants } \\
\text { Government Ministries and } \\
\text { Parastatals } \\
\text { Development Partners } \\
\text { Non-Governmental Organisations }\end{array}$ & $\begin{array}{ll}\text { - } & \text { Ministry of Finance } \\
\text { - } & \text { Ministry of Environment } \\
\text { - } & \text { Ministry of Agriculture } \\
\text { - } & \text { IDBZ } \\
\text { - } & \text { UNDP } \\
\text { - } & \text { ZERO } \\
\text { - } & \text { BCSDZ }\end{array}$ & $\begin{array}{l}\text { Key interview respondents with } \\
\text { in-depth knowledge of climate } \\
\text { finance in Zimbabwe }\end{array}$ \\
\hline
\end{tabular}

\section{Results}

Unpacking climate change risks related to investment decisions is a crucial first step to reducing such risks. However, without measuring adaptation risks and considering the prevailing investments required to address them, developing strategies to overcome relevant barriers to investment is difficult. The study noted that financing adaptation measures can be done in various ways that include funding under the UNFCCC and the Global Environment Facility (GEF). Other means are non-compliance funding, including public-private partnerships (PPPs) and foreign direct investment (FDI). Vulnerable developing countries such as Zimbabwe are over-reliant on global finance mechanisms to fight climate change, whilst their domestic finance mechanisms are incapacitated and face the near-impossible task of funding towards climate change. Thus, the sufficiency of own domestic revenues/resources is the 
key to a country's improved ability to fund towards climate change rather than waiting for donations and external funding from international organisations.

Improving the distributive fairness and effectiveness of international climate finance in developing countries depends on the accessibility of numerous funding options. It is increasingly determined by the capacities of recipient countries and especially the most vulnerable ones to absorb, manage, and implement money flows [57,65]. If domestic finance mechanisms are sound, international/global finance mechanisms should only be complementary to addressing differences in expenditure requirements and fiscal capacity across developing countries. It should be noted that own revenue sources including tax and non-tax instruments bring competence in financing; hence, vulnerable developing countries such as Zimbabwe need their revenue sources for climate financing. Consequently, international help for mainstreaming climate change adaptation into development cooperation would be aligned to partner countries' long-term goals and their development strategies. For example, respondent number 2 from the Ministry of Environment, Climate, Tourism and Hospitality Industry stated that:

"Planning and budgeting for climate change are complicated. This is demonstrated by the resources required to implement the Zimbabwe National Climate Change Response Strategy (USD 10 billion) versus the resources required to implement the Zimbabwe Nationally Determined Contribution (USD 95 billion). It is therefore, imperative that we have guidelines, tools and manuals to inform national planning and implementation of climate change interventions".

Although Zimbabwe has experienced a range of challenges, many individuals, organisations, and agencies in the country have become actively involved in resolving the impacts of climate change: "Zimbabwe produced its Initial National Communication to the UNFCCC in 1998 and 2013 its Second National Communication; consequently, a National Climate Change Response Strategy was prepared" [57]. The country's governance structure for climate change is composed of the National Climate Change Department based within the Ministry of the Environment. The National Climate Change Department has the responsibility for engaging with the UNFCCC and for producing National Communications. It also has a "National Climate Change Task Team coordinated by the Office of the President and Cabinet (OPC) with a dedicated Permanent Secretary, who receive a dedicated budget allocation from central government" [57]. The body is responsible for climate change policy analysis, formulation, and review. It also supports national climate change planning, project development, programming, implementation, and monitoring and evaluation. In support of the need for local efforts, the Zimbabwean experiences have revealed that the Environmental Management Agency (EMA) has been accredited as a national implementing entity to the Adaptation Fund.

The Adaptation Fund is thus seen as an important catalyst for climate action. These decisions have come against a backdrop of shifting weather patterns, increases in extreme weather events (droughts, floods, temperatures, hailstorms, and cyclones), and accelerated degradation of natural resources (soil erosion, deforestation, and destruction of biodiversity). These changes have made Zimbabwe one of the world's most at-risk countries to climate change even relative to other vulnerable nations. This is due to its high vulnerability and low readiness to adapt to the climate change impacts. For example, the ND-Gain Country Index ranks Zimbabwe as the fifth-least ready country, underscoring the need for investment and urgency of action to improve the country's resilience to the impacts of climate change [66]. Zimbabwe's National Climate Policy, National Climate Change Response Strategy, and Nationally Determined Contribution views adaptation as important. According to Zimbabwe's Third National Communication to the UNFCCC, climate change is an additional limitation to sustainable socio-economic development for the nation. The country is mainly vulnerable to climate change as a result of its heavy dependence on rainfed agriculture and climate-sensitive resources and sectors such as water, energy, and health [67]. 
Overall, 70\% of Zimbabwe's rural communities are dependent on rainfed agriculture; hence, decoupling rainfed agriculture from climate change is one of the country's adaptation priorities to developing resilient communities. With increasing back-to-back droughts, these communities are in constant poverty as their produce and income are affected by the frequent decrease in rains. This exacerbates the communities' adaptive capacities, and their livelihoods continue to decline over time. The upfront costs of implementing adaptation initiatives such as setting up irrigation systems require affordable and patient financing. For instance, Zimbabwe is already facing a challenge of water stress, with Bulawayo City, the secondlargest city, rationing domestic water supply during the dry season between September and November each year. Hence, water development will need to be comprehensive to include ground water exploitation and construction of multi-purpose storage works. Promotion of rainwater harvesting and sustainable water management will be important to address this water challenge that has been exacerbated by climate change $[1,68]$.

Events such as Cyclone Idai were a wake-up call for Zimbabwe as the country clearly showed limited preparedness at both local and national levels to deal with climate-related disasters. Thus, initiatives such as the Accreditation to the Adaptation Fund come as critical enablers to provide the necessary financial resources to support adaptation. They also provide opportunities for technical assistance in strengthening sectoral policies, planning, and technology development and transfers, which are critically important pillars for adaptation. Further to this, the Infrastructure Development Bank of Zimbabwe (IDBZ) was nominated as the National Implementing Entity to the Green Climate Fund. To complement its role, the Bank is in the process of establishing a Climate Finance Facility (GFF) to provide a domestic financial resource base [39,69]. It is also forming a Climate Finance Framework (CFF) that will manage the climate finance mechanism, including the structuring of green bonds, among other financial instruments, and exploring opportunities of blended financing [39]. Emphasis is also being placed on the promotion of renewable energy and efficient water use investments. For instance, in rural areas, communities' direct contributions should be made to local authorities to curb siltation in a bid to ensure the availability of water resources in rivers.

On the other hand, it was noted that the systems for managing climate change have progressed showing that the problem is indeed regarded as a priority. Despite these organisational changes to respond to climate change concerns, the government has made little effort to allocate resources for climate adaptation. Nevertheless, partnership models are increasingly accepted as being essential components of effective climate change adaptation in Zimbabwe, and a range of partnerships between civil society and the state can be observed in Zimbabwe [57]. This was further supported by respondent number 1 from the Ministry of Finance and Economic Development:

"The government is already constrained with the need to provide basic services, such as health, food and education for the people of Zimbabwe. Hence, climate adaptation will need us to foster more strategic partnerships and use the limited public resources to crowd-in private sector financing".

Further progress relates to numerous government NGO adaptation projects that emerged during the 2008 global crisis.

For example, Practical Action Southern Africa implemented a project in Masvingo, Matabeleland South, and Midlands provinces to enhance the capabilities of smallholder farmers to adapt. Community-based adaptation is also being practiced in communities such as Chiredzi, Mberengwa, Bulilimamangwe, Gwanda, Domboshava, Zvishavane, and Gutu that work with government agencies or NGOs to assess their risks of climate change hazards (see Table 5). 
Table 5. International climate change adaptation funds accessed by CSOs in Zimbabwe 2014-2018. Source [64].

\begin{tabular}{|c|c|c|c|c|}
\hline Fund Name & Project Name & $\begin{array}{l}\text { Implementing \& } \\
\text { Executing Agent(s) }\end{array}$ & Grant Received & Project Dates \\
\hline $\begin{array}{l}\text { Special Climate Change } \\
\text { Fund (GEF) }\end{array}$ & $\begin{array}{l}\text { Scaling Up Adaptation } \\
\text { to climate change, with } \\
\text { a Focus on Rural } \\
\text { Livelihoods }\end{array}$ & $\begin{array}{c}\text { Oxfam Plan } \\
\text { International Southern } \\
\text { Alliance for Indigenous } \\
\text { Resources (SAFIRE) } \\
\text { University of } \\
\text { Zimbabwe (UZ), } \\
\text { Ministry of } \\
\text { Environment, Water } \\
\text { and Climate (MEWC) }\end{array}$ & USD 3.98 million & Nov 2014-Oct 2018 \\
\hline \multirow{7}{*}{$\begin{array}{c}\text { ZRBF (SIDA, } \\
\text { DFID \& EU } \\
\text { non-climate funding }\end{array}$} & $\begin{array}{c}\text { Enhancing Community } \\
\text { Resilience and } \\
\text { Sustainability }\end{array}$ & $\begin{array}{l}\text { Consortium leader: } \\
\text { CARE }\end{array}$ & \multirow{7}{*}{$\begin{array}{l}\text { USD } 72 \text { million (USD } \\
43.2 \text { million of which is } \\
\text { climate streamed) }\end{array}$} & July 2016 to July 2019 \\
\hline & $\begin{array}{c}\text { Matabeleland } \\
\text { Enhanced Livelihoods } \\
\text { Agriculture and } \\
\text { Nutrition Adaptation } \\
\text { (MELANA) }\end{array}$ & $\begin{array}{l}\text { Consortium leader: } \\
\text { Welthungerhilfe } \\
\text { (WHH) }\end{array}$ & & July 2016 to July 2019 \\
\hline & $\begin{array}{c}\text { Zambezi Valley } \\
\text { Alliance for Building } \\
\text { Community (ZVA) }\end{array}$ & $\begin{array}{l}\text { Consortium leader: } \\
\text { Action Aid }\end{array}$ & & July 2016 to July 2019 \\
\hline & $\begin{array}{l}\text { Building Resilience } \\
\text { through improving the } \\
\text { Absorptive and } \\
\text { Adaptive Capacity for } \\
\text { Transformation } \\
\text { (BRACT) }\end{array}$ & $\begin{array}{l}\text { Consortium leader: } \\
\text { Christian Aid }\end{array}$ & & $\begin{array}{l}\text { October } 2017 \text { to } \\
\text { October } 2020\end{array}$ \\
\hline & $\begin{array}{c}\text { Enhancing Community } \\
\text { Resilience and } \\
\text { Inclusive Market } \\
\text { Systems (ECRIMS) }\end{array}$ & $\begin{array}{l}\text { Consortium leader: } \\
\text { CARE }\end{array}$ & & $\begin{array}{l}\text { October } 2017 \text { to } \\
\text { October } 2020\end{array}$ \\
\hline & $\begin{array}{l}\text { Sizimele Action for } \\
\text { Building Resilience in } \\
\text { Zimbabwe SIZIMELE }\end{array}$ & $\begin{array}{l}\text { Consortium leader: } \\
\text { DanChurchAid (DCA) }\end{array}$ & & July 2017 to July 2020 \\
\hline & $\begin{array}{l}\text { Program for Growth } \\
\text { and Resilience } \\
\text { (PROGRESS) }\end{array}$ & $\begin{array}{l}\text { Consortium leader: } \\
\text { International Rescue } \\
\text { Committee }\end{array}$ & & July 2017 to July 2020 \\
\hline $\begin{array}{l}\text { SIDA planned ZRBF } \\
\text { top-up }\end{array}$ & Unprogrammed & Unprogrammed & USD 3.35 million & 2018-to date \\
\hline SIDA & $\begin{array}{l}\text { Climate Adaptation for } \\
\text { Rural Livelihoods }\end{array}$ & Oxfam & USD 3 million & 2018-to date \\
\hline
\end{tabular}

Mainstreaming adaptation to climate change in Zimbabwe has proven relatively fruitful in the agricultural sector through community-based adaptation strategies. For example, communities from the 10 sampled districts (Domboshava, Lupane Chirumanzu, Seke, Chiredzi, Mberengwa, Bulilimamangwe, Gwanda, Zvishavane, and Gutu) practice community-based ways to build adaptive capacity. This increases their ability to predict potential hazard events and develop the ability to recover from them [58]. These areas are predominantly semi-arid, where rainfall is minimal and highly variable, making them prone to droughts. They are located in Region 5 of the country's climatic agroecological regions. Effective adaptation strategies are informed, among other factors, by agro-ecological zoning based on whether the area lies in a wet or dry zone and the type of soils. Thus, the full knowledge of the ecological environment has been useful in weighing land use 
planning options and land and water resources management practices [65]. Results have revealed that although most adaptation measures were similar, differences were based on various economic drivers in particular districts. Sources of livelihoods were similar in all districts and included casual labour, remittances from relatives elsewhere, vending, and cross-border trading. Fishing and gold panning was prevalent in areas with large water bodies, and gold mining activities were major economic drivers common in areas such as Gwanda. Some of the strategies adopted in the five different districts are shown below, as the strategies in other districts were also similar to those highlighted in Table 6.

Table 6. Adaptation strategies practised in five of the consulted districts.

\begin{tabular}{|c|c|c|}
\hline District & Agro-Ecological Zone & Adaptation Strategies \\
\hline Gwanda & $4 / 5$ & $\begin{array}{c}\text { Mopane worm harvesting } \\
\text { Gold panning } \\
\text { Wild fruits harvesting } \\
\text { Small livestock rearing } \\
\text { Small grain farming } \\
\text { Mulching } \\
\text { Replanting } \\
\text { Irrigation }\end{array}$ \\
\hline Chiredzi & 5 & $\begin{array}{l}\text { Small grain farming } \\
\text { Working in sugar plantations } \\
\text { Small livestock rearing } \\
\text { Mixed crop farming } \\
\text { Early warning systems in place }\end{array}$ \\
\hline Bulilimamangwe & $4 / 5$ & $\begin{array}{l}\text { Small grain farming } \\
\text { Small livestock rearing } \\
\text { Roof top water harvesting } \\
\text { Staggered planting }\end{array}$ \\
\hline Domboshava & 2 & $\begin{array}{c}\text { Horticulture } \\
\text { Intercropping } \\
\text { Livestock rearing }\end{array}$ \\
\hline Gutu & $3 / 5$ & $\begin{array}{l}\text { Small grain farming } \\
\text { Zero tillage } \\
\text { Irrigation } \\
\text { Mulching } \\
\text { Soil conservation } \\
\text { Water harvesting }\end{array}$ \\
\hline
\end{tabular}

Apart from community-based adaptation strategies, partnership models (publicprivate partnerships (PPPs)) are increasingly becoming vital components in developing localised climate change adaptation strategies in Zimbabwe [66], consequently, becoming a key enabler for making blended financing implementation a success. It was observed that numerous partnerships between government agencies and civil society are currently underway. It was also found that despite NGOs trying to work closely with the government, communication is suboptimal. Thus, it is noted from the study that the Adaptation Fund (AF) has raised considerable interest and hope in poorer countries such as Zimbabwe through funding from the projects under the Kyoto Protocol's Clean Development Mechanism (CDM) to support concrete adaptation activities [67].

\section{Discussions: Towards a Climate Adaptation Policy and Financing Framework}

Since the 2009 Climate Change Summit in Copenhagen, the availability of funds to finance adaptation and mitigation strategies and climate finance governance have been widely debated. The development for adaptation to climate change is regarded as a central component of climate policy in many countries. This is particularly true in Zimbabwe, but the application of adaptation actions in the country is in its early stages. Consideration of 
climate change and its impacts has become clearer; however, the accessibility of practical guidance on adaptation has failed to keep a pace that calls for holistic criteria for adaptation of financing mechanisms. Climate change adaptation in Zimbabwe, therefore, lacks the key financing policy framework to fully operationalise climate adaptation, even though significant efforts in compiling national communications and formulating the climate change strategy have gained the necessary momentum.

The architecture supporting climate adaptation projects does not have a policy direction or instruments sufficient to allow the partners and private sector to invest with confidence [64]. In Zimbabwe, practical solutions to the climate adaptation challenge would need a harmonized relationship between the private and public sector, which is lacking. This has created a distortionary focus towards "planning for climate adaptation" either at the global level through international institutions or at the state level through national governments. Sound climate change policies ought to stimulate confidence to overcome adaptation barriers, thus paving the way for effective action and a better engagement environment with stakeholders. There are nonetheless divergent views regarding what constitutes adaptation between the national governments and the international institutions. This creates a blurred perspective about the assessment of how well project sponsors and beneficiaries make the most of climate adaptation finance. This hurts the capacity to develop or implement climate policy at the national level, as well as integration of climate change into the national budget guidelines. Zimbabwe has been no exception in this regard.

Despite the efforts to produce a climate change bill and governance structure, several barriers exist that are retarding the adoption of adaptation practices at the scale that is required in Zimbabwe. The emergence of this great variety of climate governance arrangements has led to a noteworthy increase in the institutional complexity of Zimbabwe's climate policy making. Furthermore, due to a continuous change of ministries, there is mistrust arising from ministries and agencies that formerly had a considerable impact on climate change policies in Zimbabwe. Climate change matters are also covered by several uncoordinated sectoral policies, strategies, and action plans [53]. Climate change problems should become mainstreamed into all sectors; however, this has not happened in agriculture, land-use planning, natural resource management, or secondary industries.

Zimbabwe cannot yet conduct precise estimations of financial requirements to address climate change adaptation and mitigation measures. This is a prerequisite for designing bankable projects to attract climate financing and to set up institutional arrangements for collective decision-making to incorporate climate change in budgets and plans. Inadequate availability of data and limited expertise lead to (i) challenges in data analyses; (ii) challenges in evaluating accurate data on adaptation financing, policies, and actions; and (iii) complications in the identification of funds and the procedures to access them. Therefore, the Government of Zimbabwe can fruitfully explore the highlighted Climate Adaptation Financing Framework to inform policy and foster climate action.

The financing framework should also consider pertinent cross-cutting elements such as gender, environmental and social safeguards, and climate de-risking. Furthermore, coordination of climate change adaptation and financing of the prioritised activities will enhance communities' capacity to adapt to the impacts of climate change and to build resilience. Clear institutional and legal arrangements are also important for the successful establishment of an effective and efficient framework. Finally, there is a need for a clear governance system that supports the engagement of strategic partners with well-defined roles and responsibilities (Figure 2). Figure 2 shows the proposed coordination framework.

To sum up, the two frameworks are useful for both the establishment of sustainable climate adaptation finance for Zimbabwe and also giving direction in the actual implementation of the climate adaptation programmes and projects. Local climate adaptation finance will go a long way in leveraging global and domestic climate financing towards building an enhanced adaptive and climate-resilient Zimbabwe. The institutional governance framework will provide appropriate coordination, certainty, and confidence concerning the road map and interventions to deal with climate change challenges. 


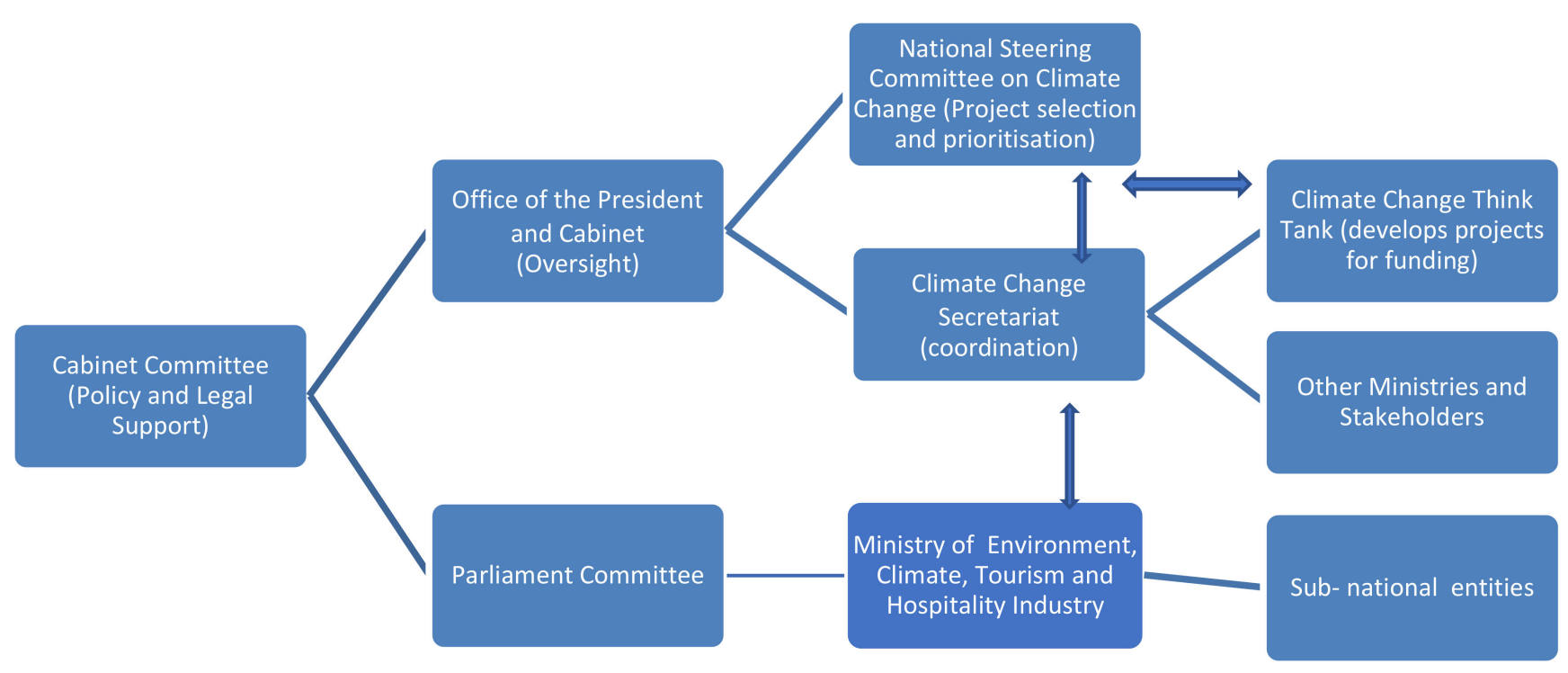

Figure 2. Climate adaptation institutional governance framework.

\section{Lessons, Policy Options, and Implications}

This article has brought new insights and lessons to the fore for consideration by developing countries concerning climate adaptation financing, policy formulation, and implementation. These insights do not feature prominently in the literature reviewed above. Generally, there is a need for a concerted and integrated approach to resolving climate adaptation financing challenges in developing countries if progress is to be made and positive results are to be realised.

Firstly, there is a need for the formulation of climate financing adaptation policy and legislative frameworks. As in the case of Zimbabwe and any other developing countries struggling with a lack of policy directions, concerted efforts must formulate and align climate adaptation financing and implementation strategies. Any such policies related to climate adaptation financing must also be harmonised. Policies and processes across ministries and all implementing agencies must be coordinated to actively seek synergies across policy frameworks.

Secondly, local climate adaptation financing mechanisms must be established. Developing nations must establish climate adaptation financial mechanisms to support enhanced adaptive capacity, set up sustainable development climate change adaptation investments, and foster national resilience.

Thirdly, strategic partnerships are a key enabler for gathering climate finance from diverse sources including global multilateral and bilateral funds, development finance institutions, the private sector, and philanthropic institutions. The adaptation financing framework for Zimbabwe should explore opportunities for supporting blended funding and gathering private sector financing domestically and internationally for supporting impact adaptation at the national level. The framework should consolidate all the national efforts, including the work by the Ministry of Finance, IDBZ, EMA and the Climate Change Management Department, to support transformational adaptation climate financing, including building on each partner's strengths.

Fourthly, stakeholder identification and engagement in climate finance adaptation and policing is very critical. To prioritise investments in climate change adaptation, there is a need to unpack localized climate risks and how adaptation can be used in de-risking some investments. Solid climate adaptation execution processes and policies need to be put in place to support policy guidelines. 


\section{Conclusions}

Understanding the risks associated with investment decisions when dealing with climate change is critical. Regular monitoring and disclosure aid in measuring the effectiveness of interventions over time. Thus, failure by governments and businesses to evaluate and act on their climate risks can result in more problems in accessing capital. Tracking investments in adaptation is also significant in evaluating adaptation finance to climate-sensitive sectors (agriculture and water resources) and geographies that have high climate risks such as in Chiredzi, Gwanda, and Zvishavane. Hence, it can assist in forming the basis for prioritising future investment and the identification of sources of financing. This tailors well with the opinions by the [5] on how its toolkit offers provision for technical and practical answers. This toolkit identifies and supports adaptation as a national priority, improves national capacities, and enables environments to attract investments from a wide variety of sources.

This article contributes to the emerging but urgent discourse on climate change financing. Utilising data from strategic actors on the ground, the study clarifies the opportunities and challenges that have been experienced in Zimbabwe. These experiences can serve as "teachable moments" for other countries seeking to embark on a similar process. In addition, the article highlights the promises of resolving climate adaptation financing challenges in developing countries. This can motivate various funding partners to invest more actively in this endeavour, working with the public and private sectors and exploring the novel opportunities of blended financing in funding adaptation interventions.

Author Contributions: Conceptualization, I.C., T.G. and V.N.G.-J.; methodology, W.Z., T.K., R.D. and T.M.; software, T.G., T.K. and R.D.; validation, I.C., T.G. and T.M.; formal analysis, V.N.G.-J., I.C. and T.G.; investigation, V.N.G.-J. and W.Z.; resources, T.G.; data curation, T.K. and R.D.; writing-original draft preparation, I.C., T.G., V.N.G.-J. and T.M.; writing-review and editing, I.C., T.G., V.N.G.-J. and T.M.; visualization, V.N.G.-J. and T.M.; supervision, I.C. and T.G.; project administration, I.C and T.G.; funding acquisition, T.G. All authors have read and agreed to the published version of the manuscript.

Funding: This work was funded by research funds of individual co-authors to enable proof reading and editing and the APC was funded by the University of Johannesburg Library publications support Fund.

Informed Consent Statement: Informed consent was obtained from all subjects involved in the study.

Data Availability Statement: Not applicable.

Conflicts of Interest: The authors declare no conflict of interest.

\section{References}

1. GoZ. Zimbabwe's National Climate Change Response Strategy, Minister of Environment, Water and Climate; GoZ: Harare, Zimbabwe, 2015.

2. Billi, M.; Blanco, G.; Urquiza, A. What is the 'Social' in Climate Change Research? A Case Study on Scientific Representations from Chile. Minerva 2019, 57, 293-315. [CrossRef]

3. United Nations Development Programme (UNDP). Promoting Sustainable Development Through More Effective Civil Society Participation in Environmental Governance: A Selection of Country Case Studies from the EU-NGOs Project; UNDP: New York, NY, USA, 2016.

4. International Organization for Migration (IOM). Migration, Environment and Climate Change: Assessing the Evidence; IOM: Geneva, Switzerland, 2009.

5. Gagnon-Lebrun, F.; Agrawala, S. Progress on Adaptation to Climate Change in Developed Countries: An Analysis of Broad Trends; ENV/EPOC/GSP (2006)1/FINAL; OECD: Paris, France, 2006.

6. Lorenz, S.; Dessai, S.; Forster, P.M.; Paavola, J. Adaptation planning and the use of climate change projections in local government in England and Germany. Reg. Environ. Chang. 2017, 17, 425-435. [CrossRef] [PubMed]

7. Mertz, O.; Halsnaes, K.; Olesen, J.E.; Rasmussen, K. Adaptation to Climate Change in Developing Countries. Environ. Manag. 2009, 43, 743-752. [CrossRef]

8. Ioris, A.A.R.; Irigaray, C.T.; Girard, P. Institutional responses to climate change: Opportunities and barriers for adaptation in the Pantanal and the Upper Paraguay River Basin. Clim. Chang. 2014, 127, 139-151. [CrossRef]

9. Bhatasara, S.; Nyamwanza, A. Sustainability: A missing dimension in climate change adaptation discourse in Africa? J. Integr. Environ. Sci. 2018, 15, 83-97. [CrossRef]

10. Chersich, M.F.; Wright, C.Y. Climate change adaptation in South Africa: A case study on the role of the health sector. Glob. Health 2019, 15, 1-16. [CrossRef] [PubMed] 
11. Nakhooda, S.; Forstater, M. The Effectiveness of Climate Finance: A Review of the Global Environment Facility. Research Reports and Studies-October 2013, Overseas Development Institute; 203 Blackfriars Road, London, SE1 8NJ. 2013. Available online: https:/ / www.odi.org/publications/7916-effectiveness-climate-finance-review-global-environment-facility (accessed on 16 February 2021).

12. Mbaku, J.M. The Controversy Over the Grand Ethiopian Renaissance Dam, Africa In Focus; Brookings: Washington, DC, USA, 2020.

13. Mokany, K.; Ferrier, S. Predicting Impacts of Climate Change on Biodiversity: A Role for Semi-Mechanistic Community-Level Modelling, Diversity and Distributions; Blackwell Publishing Limited: Hoboken, NJ, USA, 2011; Volume 17, pp. 374-380. [CrossRef]

14. Tompkins, E.L.; Boyd, E.; Nicholson-Cole, S.A.; Weatherhead, K.; Arnell, N.W.; Adger, W.N. An Inventory of Adaptation to Climate Change in the UK: Challenges and Findings. Working Paper 135; Tyndall Centre for Climate Change Research, Univ. of East Anglia: Norwich, UK, 2009.

15. Biesbroek, G.R.; Termeer, C.J.A.M.; Klostermann, J.E.M.; Kabat, P. On the nature of barriers to climate change adaptation. Reg. Environ. Chang. 2013, 13, 1119-1129. [CrossRef]

16. Eisenack, K.; Moser, S.; Hoffmann, E.; Klein, R.; Oberlack, C.; Pechan, A.; Rotter, M.; Termer, C.J.A.M. Explaining and overcoming barriers to climate change adaptation. Nat. Clim. Chang. 2014, 4, 867-872. [CrossRef]

17. Yohe, G.; Tol, R.S.J. Indicators for social and economic coping capacity-Moving toward a working definition of adaptive capacity. Glob. Environ. Chang. 2002, 12, 25-40. [CrossRef]

18. Moser, S.C. Are our levers long and our fulcra strong enough? Exploring the soft underbelly of adaptation decisions and actions. In Adapting to Climate Change: Thresholds, Values, Governance; Adger, W.N., Lorenzoni, I., O'Brien, K., Eds.; Cambridge University Press: Cambridge, UK, 2009; pp. 313-334.

19. Kundzewicz, Z.W.; Mata, L.J.; Arnell, N.W.; Döll, P.; Kabat, P.; Jiménez, B.; Miller, K.A.; Oki, T.; Sen, Z.; Shiklomanov, I. Freshwater resources and their management. In Climate Change 2007: Impacts, Adaptation and Vulnerability. Contribution of Working Group II to the Fourth Assessment Report of the Intergovernmental Panel on Climate Change; Parry, M.L., Canziani, O.F., Palutikof, J.P., van der Linden, P.J., Hanson, C.E., Eds.; Cambridge University Press: Cambridge, UK, 2007; pp. 173-210.

20. Ivey, J.L.; Smithers, J.; de Loë, R.C.; Kreutzwiser, R.D. Community capacity for adaptation to climate-induced water shortages: Linking institutional complexity and local actors. Environ. Manag. 2004, 33, 36-47. [CrossRef]

21. Pan, J.; Zheng, Y. Analytical Framework and Policy Implications on Adapting to Climate Change. China Population. Resour. Environ. 2010, 20, 1-5. [CrossRef]

22. UNFCCC. Climate Change: Impacts, Vulnerabilities and Adaptation. 2007. Available online: https://unfccc.int/resource/docs/ publications/impacts.pdf (accessed on 2 February 2021).

23. Muller, J.C. Adapting to climate change and addressing drought-Learning from the Red Cross Red Crescent experiences in the Horn of Africa. Weather Clim. Extrem. 2014, 3, 31-36. [CrossRef]

24. Joakim, E.; Mortsch, L.; Oulahen, G. Using vulnerability and resilience concepts to advance climate change adaptation. Environ. Hazard. 2015, 14, 137-155. [CrossRef]

25. Eakin, H. Human Vulnerability to Global Environmental Change. In Encyclopedia of Earth. 2008. Available online: www.eoearth. org/article/Human_vulnerability_to_global_enronmental_change (accessed on 26 January 2021).

26. Ludena, C.E.; Yoon, S.W. Local Vulnerability Indicators and Adaptation to Climate Change: A Survey; Technical Note No. 857 (IDB-TN857); Inter-American Development Bank: Washington, DC, USA, 2015.

27. Zhao, C.; Yan, Y.; Wang, C.; Tang, M.; Wu, G.; Ding, D.; Song, Y. Adaptation and mitigation for combating climate change-From single to joint. Ecosyst. Health Sustain. 2018, 4, 85-94. [CrossRef]

28. IPCC. Managing the Risks of Extreme Events and Disasters to Advance Climate Change Adaptation. A Special Report of Working Groups I and II of the Intergovernmental Panel on Climate Change; Field, C.B.V., Barros, T.F., Stocker, D., Qin, D.J., Dokken, K.L., Ebi, M.D., Mastrandrea, K.J., Mach, G.-K., Plattner, S.K., Allen, M., Eds.; Cambridge University Press: Cambridge, UK; New York, NY, USA, 2012; 582p.

29. Du Bois, K.M.; Kanamori, H.; Seeberg-Elverfeldt, C. Incorporating Climate Change Considerations into Agricultural Investment Programmes a Guidance Document; FAO: Rome, Italy, 2012.

30. Barthe, M. ERGO-METH: Principes d'une Méthodologie D'informatisation Visant à Intégrer les Apports de L'ergonomie Cognitive dans la Démarche de Conception pour Améliorer L'utilité et la Maniabilité des Logiciels Interactifs de Gestion; Mémoire d'ingénieurs du CNAM: Paris, France, 1997.

31. World Economic Forum. Climate Adaptation: Seizing the Challenge: 91-93 Route de la Capite CH-1223; World Economic Forum: Cologny, Switzerland, 2014.

32. Grafakos, S.; Pacteau, C.; Delgado, M.; Landauer, M.; Lucon, O.; Driscoll, P. Integrating Mitigation and Adaptation: Opportunities and Challenges; Cambridge University Press: New York, NY, USA, 2018; pp. 101-138.

33. Global Environmental Facility (GEF). The A to Z of the GEF. A Guide to the Global Environment Facility. 2015. Available online: https:/ / wedocs.unep.org/bitstream/handle/20.500.11822/13742/Guide_to_the_GEF_for_NGOs.pdf?sequence= 1\&isAllowed =y (accessed on 26 February 2021).

34. Bird, N.; Watson, C.; Schalatek, L.; Keil, C. Climate Finance Fundamentals 3: Adaptation Finance (2017 Update); Publication Series: December 2017; Overseas Development Institute; 203 Blackfriars Road, London, SE1 8NJ. 2017. Available online: https://www. odi.org/publications/11053-climate-finance-fundamentals-3-adaptation-finance-2017-update (accessed on 26 February 2021). 
35. IPCC. Climate Change 2014 Synthesis Report. Contribution of Working Groups I, II and III to the Fifth Assessment Report of the Intergovernmental Panel on Climate Change; Core Writing Team, Pachauri, R.K., Meyer, L.A., Eds.; IPCC: Geneva, Switzerland, 2014; $151 \mathrm{p}$.

36. Adger, W.N.; Huq, S.; Brown, K.; Conway, D.; Hulme, M. Adaptation to climate change in the developing world. Prog. Dev. Stud. 2003, 3, 179-195. [CrossRef]

37. Phuong, G.; Biesbroek, R.; Wals, A.E.J. Barriers and enablers to climate change adaptation in hierarchical governance systems: The case of Vietnam. J. Environ. Policy Plan. 2018, 20, 518-532. [CrossRef]

38. Smit, B.; Pilifosova, O. Adaptation to Climate Change in the Context of Sustainable Development and Equity; IPCC Working Group II; Cambridge University Press: Cambridge, UK, 2001; pp. 877-912.

39. Thirdway Africa. Inclusive Business, Impact Investing and Blended Finance. Zimbabwe Resilience Building Fund Breakfast Meeting; UNDP: Harare, Zimbabwe, 2018.

40. Brooks, N.; Anderson, S.; Ayers, J.; Burton, I.; Tellam, I. Tracking Adaptation and Measuring Development; IIED Climate Change Working Paper No. 1; IIED: London, UK, 2011.

41. Adger, W.N. Social Capital and Climate Change; Working Paper 8; Tyndall Centre for Climate Change Research, University of East Anglia: Norwich, UK, 2001.

42. Burton, I.; Malone, E.; Huq, S. Adaptation Policy Frameworks for Climate Change: Developing Strategies, Policies and Measures Edited by Bo Lim Erika Spanger-Siegfried United Nations Development U N Programme; UNDP: New York, NY, USA, 2004.

43. Adger, W.N.; Agrawala, S.; Mirza, M.M.Q.; Conde, C.; O’Brien, K.; Pulhin, J.; Pulwarty, R.; Smit, B.; Takahashi, K. Assessment of Adaptation Practices, Options, Constraints and Capacity. Climate Change 2007: Impacts, Adaptation and Vulnerability; Cambridge University Press: Cambridge, UK, 2007; pp. 717-743.

44. Burton, I. Vulnerability and adaptive response in the context of climate and climate change. Clim. Chang. 1997, 36, 185-196. [CrossRef]

45. Mohabbat, K.M.; Shahriar, I.M. Climate change adaptation in developing countries: Does globalization act as facilitator? J. Glob. Stud. 2015, 6, 62-74.

46. Kates, R.W.; Travis, W.R.; Wilbanks, T.J. Transformational Adaptation When Incremental Adaptations to Climate Change Are Insufficient. Proc. Natl. Acad. Sci. USA 2012, 109, 7156-7161. [CrossRef]

47. Wise, R.M.; Fazey, I.; Smith, M.S.; Park, S.E.; Eakin, H.C.; Van Garderen, E.A.; Campbell, B. Reconceptualising adaptation to climate change as part of pathways of change and response. Glob. Environ. Chang. 2014, 28, 325-336. [CrossRef]

48. Brazier, A. Climate Change in Zimbabwe: A Guide for Planners and Decision-Makers; Konrad-Adenauer-Stiftung: Harare, Zimbabwe, 2018.

49. Ackerman, F. G-24 Discussion Paper Series Financing the Climate Mitigation and Adaptation Measures in Developing Countries, United Nations. Nat. Clim. Chang. (pp. 1-17). Working Paper WP-US-0910. 2009. Available online: http://frankackerman.com/ publications/climatechange/Financing_Climate_Mitigation.pdf (accessed on 18 February 2021).

50. Flynn, C. Blending Climate Finance through National Climate Funds: A Guidebook for the Design and Establishment of National Funds to Achieve Climate Change Priorities; United Nations Development Programme: New York, NY, USA, 2011.

51. Yannick, G. Catalysing Climate Finance: A Guidebook on Policy and Financing Options to Support Green, Low-Emission and ClimateResilient Development; United Nations Development Programme: New York, NY, USA, 2011.

52. Meirovich, H.; Peters, S.; Rios, A.R. Financial Instruments and Mechanisms for Climate Change Programs in Latin America and the Caribbean (IDB Policy Brief; 212). 2013. Available online: https://publications.iadb.org/publications/english/document/ Financial-Instruments-and-Mechanisms-for-Climate-Change-Programs-in-Latin-America-and-the-Caribbean-A-Guide-forMinistries-of-Finance.pdf (accessed on 15 January 2021).

53. World Bank. Crowdfunding's Potential for the Developing World. InfoDev, Finance and Private Sector Development Department; World Bank: Washington, DC, USA, 2013.

54. Climate Policy Initiative. Understanding and Increasing Finance for Climate Adaptation in Developing Countries. A CPI Report; Climate Policy Initiative: Cologne, Germany, 2018.

55. Nakhooda, S.; Caravani, A.; Bird, N. Climate Finance in Sub-Saharan Africa Climate Finance Policy Brief; Overseas Development Institute and Liane Schalatek, Heinrich Böll Stiftung North America: Cologne, Germany, 2011.

56. Gutsa, I. Climate change and policy making in Zimbabwe. In search of evidence-based policy making? Acta Univ. 2014, 24, 21-28. [CrossRef]

57. Bécault, E.; Koenig, M.; Marx, A. Getting Ready For Climate Finance: The Case of Rwanda. Belgian Policy Research Group on Financing for Development; Working Paper N ${ }^{\circ} 13$ September 2016; BeFind: Namur, Belgium, 2016.

58. David, D.; Matlin, D. The national and local politics of climate change adaptation in Zimbabwe. Clim. Dev. 2014, 7, 1-12. [CrossRef]

59. Brown, D.R.; Chanakira, K.; Chatiza, M.; Dhliwayo, D.; Dodman, M.; Masiiwa, M.; Muchadenyika, D.P.; Mugabe, P.; Zvigadza, S. Climate Change Impacts, Vulnerability and Adaptation in Zimbabwe; IIED Climate Change Working Paper No. 3; IIED: London, UK, 2012.

60. Katjiua, M. Scaling up Community Resilience (SCORE) to Climate Variability and Climate Change in Northern Namibia, Synthesis Report; Polytechnic of Namibia: Windhoek, Namibia, 2014.

61. UNEP. UNEP's Adaptation Finance Gap Report 2016. United Nations Environment Programme (UNEP). Nairobi, Kenya, 2016. Available online: http:/ / www.unepdtu.org/newsbase/2016/05/uneps-adapta-tion-finance-gap-report-released?id=377aa3 d4-32c1-4100-8bee-ae65390b60ba (accessed on 10 December 2020). 
62. Zvirevo, W. Green Financing in Zimbabwe: Case of the Infrastructure Development Bank of Zimbabwe, Elephant Hills Hotel, Victoria Falls, Zimbabwe 6 June 2019; Infrastructure Development Bank of Zimbabwe: Harare, Zimbabwe, 6 June 2019.

63. Herald. 12 August: US\$3m for Climate Change Projects; Zimpapers: Harare, Zimbabwe, 2019.

64. Lorimer, E.; Zvigadza, S.; Shava, C.; Parring, S. Opportunities for Accessing International Climate Adaptation Finance for Civil Society Organizations in Zimbabwe; Bread for the World, Protestant Development Services: Johannesburg, South Africa, 2018.

65. Chikodzi, D.; Zinhiva, H.; Simba, F.M.; Murwendo, T. Reclassification of agro-ecological zones in Zimbabwe-The rationale, methods and expected benefits: The case of Masvingo Province. J. Sustain. Dev. Afr. 2013, 15, 104-116.

66. Notre Dame Global Adaptation Initiative. Rank Countries by ND-GAIN Country Index, Vulnerability and Readiness; University of Notre Dame: Notre Dame, IN, USA, 2018.

67. Government of Zimbabwe. Zimbabwe Third National Communication to the United Nations Framework Conference on Climate Change Visual Works $P \backslash L$; Government of Zimbabwe: Harare, Zimbabwe, 2016.

68. Zimbabwe Vulnerability Assessment Committe. Zimbabwe Vulnerability Assessment Committee (ZimVAC) 2016 Rural Livelihoods Assessment, Food and Nutrition Council; Zimbabwe Vulnerability Assessment Committee: Harare, Zimbabwe, 2016.

69. Urama, K.C.; Ozor, N. Impacts of Climate Change on Water Resources in Africa: The Role of Adaptation; African Technology Policy Studies Network: Nairobi, Kenya, 2010. 